\begin{tabular}{cc}
\hline $\begin{array}{c}\text { Araştırma Makalesi / Research Article } \\
\text { doi: } 10.18678 / \mathrm{dtfd} .638625\end{array}$ & Düzce Tıp Fakültesi Dergisi / Duzce Medical Journal \\
\hline
\end{tabular}

\title{
Is the Sleep Perception of Obstructive Sleep Apnea Patients Reliable?
}

\author{
Obstrüktif Uyku Apnesi Hastalarının Uyku Algıları Güvenilir mi?
}

\author{
Pinar YILDIZ GÜLHAN \\ (i) 0000-0002-5347-2365 \\ Ege GÜLEÇ BALBAY \\ (10) 0000-0002-1557-7019 \\ Ali Nihat ANNAKKAYA \\ (D) 0000-0002-7661-8830
}

Düzce University Medical Faculty Department of Chest Diseases, Düzce, Turkey

\section{Sorumlu Yazar \\ Corresponding Author Pınar YILDIZ GÜLHAN pinaryildiz691@hotmail.com}

Geliş Tarihi / Received : 26.10 .2019 Kabul Tarihi / Accepted : 16.12.2019 Çevrimiçi Yayın Tarihi / Available Online

\begin{abstract}
Aim: The aim of this study, is to evaluate the consistency with the polysomnography (PSG) data of the patients and the data reported by the patients themselves after PSG examination in the morning.

Material and Methods: One hundred and thirty-four consecutive individuals who were admitted to the Chest Disease Polyclinic for Sleep Disorders of Duzce University Medical Faculty were included in the study. PSG and the questions related to sleep perception was applied by the same physician with face to face interview to all participants.

Results: Of the patients included in the study 90 (67.2\%) were male and $44(32.8 \%)$ were female, and the mean age was $47.3 \pm 12.6$ years. While there was a significant correlation $(p=0.042, r=0.301)$ between the sleep time reported by the patients themselves after waking up in the morning and the sleep time measured by the PSG in patients without obstructive sleep apnea (OSA), there was no correlation in OSA $(+)$ patients $(\mathrm{p}=0.269, \mathrm{r}=0.125)$. Similarly, while there was a significant correlation $(\mathrm{p}=0.026, \mathrm{r}=0.352)$ between the sleep latency reported by the patients themselves after waking up in the morning and the sleep latency measured by the PSG in OSA (-) patients, there was no correlation in OSA (+) patients $(\mathrm{p}=0.060, \mathrm{r}=0.223)$. Conclusion: While evaluating OSA patients and explaining their treatment before and after PSG, it should be kept in mind that they might have impaired perception. Therefore, we thought that we should spend more time to patients, and to make our explanations more clearly and understandably.
\end{abstract}

Keywords: Perception; sleep apnea.

ÖZ

Amaç: Bu çalışmanın amacı, hastaların polisomnografi (PSG) verileri ile PSG incelemesi sonrası sabah hastaların kendileri tarafindan bildirilen verilerin birbiri ile uyumunu değerlendirmektir.

Gereç ve Yöntemler: Çalışmaya Düzce Üniversitesi Tıp Fakültesi Göğüs Hastalıkları Uyku Polikliniği'ne başvurmuş ardışı 134 kişi dahil edildi. PSG ve uyku algısı ile ilgili sorular tüm katılımcılara aynı hekim tarafından yüz yüze görüşme ile uygulandı.

Bulgular: Çalışmaya dahil edilen hastaların 90'^ $(\% 67,2)$ erkek ve 44'ü $(\% 32,8)$ kadın olup yaş ortalaması $47,3 \pm 12,6$ y1l idi. Obstrüktif uyku apnesi (OUA) negatif olan hastalarda, hastaların sabah uyandıktan sonra kendileri tarafından bildirilen uyku süresi ile PSG cihazı ile ölçülen uyku süresi arasında anlamlı bir korelasyon varken $(\mathrm{p}=0,042 ; \mathrm{r}=0,301)$, OUA (+) olan hastalarda hastaların sabah uyandıktan sonra kendileri tarafindan bildirilen uyku süresi ile PSG cihazı ile ölçülen uyku süresi arasında korelasyon yoktu ( $\mathrm{p}=0.269, \mathrm{r}=0.125)$. Benzer şekilde, OUA (-) olan hastalarda hastaların sabah uyandıktan sonra kendileri tarafindan bildirilen uyku latansı ile PSG cihazı ile ölçülen uyku latansı arasında anlamlı bir korelasyon varken $(\mathrm{p}=0.026, \mathrm{r}=0.352)$, OUA $(+)$ olan hastalarda hastaların sabah uyandıktan sonra kendileri tarafindan bildirilen uyku latansı ile PSG cihazı ile ölçülen uyku latansı arasında korelasyon yoktu ( $\mathrm{p}=0.060, \mathrm{r}=0.223)$.

Sonuç: OUA hastalarını değerlendirirken ve hastaların PSG sonrası ve öncesi tedavilerini açıklarken, hastaların algılarının bozulmuş olabileceği akılda tutulmalıdır. Bu nedenle, hasta ile görüşmelerde daha çok zaman ayırmak ve açıklamalarımızı daha açık ve anlaşılır bir şekilde yapmak gerektiğini düşünmekteyiz.

Anahtar kelimeler: Alg1; uyku apnesi. 


\section{INTRODUCTION}

The most common type of sleep disordered breathing (SDB) is obstructive sleep apnea (OSA) (1). OSA characterized by repetitive collapse of the upper airway during sleep and this condition leading to oxygen desaturation, sympathetic activation, and recurrent arousals. Previous studies point out that OSA is associated with high morbidity and mortality and indicate a causal relationship between OSA and many diseases including cardiovascular disease, diabetes mellitus, and neurocognitive dysfunction $(2,3)$.

Cognitive processing, sustained attention, executive functioning, and memory have all been reported to be impaired in OSA. However, the causal mechanisms of these deficits have not been entirely clarified, and the relative contribution of intermittent hypoxia and sleep disruption in OSA is particularly controversial (4).

In this study, it is aimed to evaluate the consistency with the polysomnography (PSG) data of the patients and the data reported by the patients themselves after PSG examination in the morning. In this way, we planned to compare the sleep perceptions of OSA patients with objective measurements.

\section{MATERIAL AND METHODS \\ Study Group}

One hundred and thirty-four consecutive individuals who were admitted to the Chest Disease Polyclinic for Sleep Disorders of Duzce University Medical Faculty were included in the study. Ethics committee approval was received for this study from the ethics committee of Duzce University Medical Faculty (dated 21.10.2019 and numbered 227). PSG and the questions related to sleep perception was applied by the same physician with face to face interview to all participants. Informed consent was obtained from all study participants. Individuals under 18 years of age, and pregnant women were excluded.

\section{Polysomnography (PSG)}

PSG was performed on all patients for a minimum of 6 hours. A PSG digital system was used (Alice 5 Sleep System, Philips, Respironics, Pennsylvania, United States). At the same time electroencephalography, electrooculography, chin electromyography, oral and nasal airflow (nasal-oral 'thermistor' and nasal cannula), thorax movements, abdominal movements, arterial oxygen saturation (pulse oximetry instrument), electrocardiography and snoring recordings ( $>6$ hours) were obtained from all patients. The same device was used for all of these parameters. All records were scored manually in computer environment. Apnea Hypopnea Index (AHI) is represented by the number of apnea and hypopnea events per hour of sleep. Patients with AHI $\geq 5$ were diagnosed with OSA. The severity of OSA was considered as follows (5): normal (AHI <5); mild sleep apnea (AHI 5-15); moderate sleep apnea (AHI 16-30); and severe sleep apnea (AHI >30).

\section{Questions}

The questions asked to patients about the duration of night sleep are as follows:

1. How long does it take you to fall asleep? (Answer as minutes)

2. How many hours did you sleep during the night?

3. Do you remember how long you were awake during the night?

4. How long did you stay awake during the night?

\section{Statistical Analysis}

Data were analyzed using the SPSS v.20 statistical package. Descriptive statistics (mean \pm standard deviation, median, minimum, maximum) of all variables were calculated. Firstly, whether the normality of distribution of variables was examined by Kolmogorov-Smirnov test. Nonparametric tests were used because the data was not appropriate normal distribution. According to the severity of OSA, Kruskal-Wallis Test was used in the comparison of groups in terms of numerical data. Mann-Whitney U test was used in binary subgroup comparisons and Bonferroni correction was performed. Chi-Square test was used to examine the relationships between categorical variables and Spearman's non-parametric correlation test was used in all correlation analyzes. A p value $<0.05$ was considered statistically significant.

\section{RESULTS}

Ninety (67.2\%) male and 44(32.8\%) female patients were included in the study. The mean age of the patients included in the study was $47.3 \pm 12.6$ years. OSA was negative in $48(35.8 \%)$ cases while $86(64.2 \%)$ were positive. Based on AHI values, OSA severity was reported as mild among 34 (25.4\%), moderate among 22 (16.4\%), and severe among $30(22.4 \%)$ patients. General characteristics of the patients are given in Table 1 .

Sleep efficacy was statistically increased with increasing severity of OSA $(\mathrm{p}=0.001)$, and this increase was significant for all subgroups of OSA patients $(\mathrm{p}<0.0083$, according to Bonferroni correction). In the subgroup analysis, only in severe OSA patients, arousal index and body mass index (BMI) were significantly higher than OSA (-) patients $(\mathrm{p}=0.006, \mathrm{p}<0.0083$, according to Bonferroni correction). The general characteristics of patients according to the severity of OSA and their PSG findings are shown in Table 2.

When the patients were evaluated according to whether they remember the awake time during the night or not, $23.1 \%(n=31)$ patients did not remember the awake time during the night, in total. Of these 31 patients, $8.3 \%(n=4)$ of OSA (-) patients and $31.4 \%(n=27)$ of OSA (+) patients reported that they did not remember the awake time during the night $(\mathrm{p}=0.002$, Table 3$)$.

Table 1. General characteristics of patients

\begin{tabular}{lc}
\hline Characteristics & n (\%) or mean \pm SD (min-max) \\
\hline Gender & \\
Male & $90(67.2)$ \\
Female & $44(32.8)$ \\
Age (years) & $47.3 \pm 12.6(18-85)$ \\
BMI (kg/m²) & $33.4 \pm 7.8(18-73)$ \\
OSA (+) & $86(64.2)$ \\
Mild OSA & $34(25.4)$ \\
Moderate OSA & $22(16.4)$ \\
Severe OSA & $30(22.4)$ \\
Comorbidities & $102(76.1)$ \\
None & $19(14.2)$ \\
Lung diseases & $16(14.2)$ \\
Heart diseases & $3(2.2)$ \\
Thyroid diseases
\end{tabular}

SD: Standard Deviation, Min: Minimum, Max: Maximum, BMI: Body Mass Index; OSA: Obstructive Sleep Apnea 
Table 2. The comparison of clinical and polysomnographic features of patients with and without obstructive sleep apnea

\begin{tabular}{|c|c|c|c|c|c|}
\hline $\begin{array}{l}\text { Clinical and } \\
\text { polysomnographic features }\end{array}$ & $\begin{array}{c}\text { OSA (-) } \\
(\mathrm{n}=48)\end{array}$ & $\begin{array}{c}\text { Mild OSA } \\
(\mathrm{n}=34)\end{array}$ & $\begin{array}{c}\text { Moderate OSA } \\
(\mathrm{n}=\mathbf{2 2})\end{array}$ & $\begin{array}{c}\text { Severe OSA } \\
(\mathrm{n}=\mathbf{3 0})\end{array}$ & $\mathbf{p}$ \\
\hline Age (years) & $40.0(22-70)$ & $47.5(23-69)$ & $47.5(28-73)$ & $44.0(27-74)$ & 0.288 \\
\hline BMI (kg/m2) & $28.9(23.3-49.1)$ & $31.5(22.5-73.5)$ & $33.3(24.7-62.8)$ & $35.9(22.3-62.4)$ & 0.001 \\
\hline AHI (event/h of sleep) & $1.75(0.0-4.5)$ & $8.25(5.1-13.4)$ & $21.5(14.1-29.0)$ & $54.25(30.5-99.3)$ & $<0.001$ \\
\hline TST (min) & $337.0(168.0-473.8)$ & $339.7(144.1-451.0)$ & $361.0(204.0-458.0)$ & $340.25(98.5-470.0)$ & 0.298 \\
\hline Sleep efficacy $(\%)$ & $77.6(41.3-94.2)$ & $75.3(8.0-96.4)$ & $85.7(45.6-98.1)$ & $83.9(68.4-99.0)$ & 0.001 \\
\hline Arousal index (event/h of sleep) & $7.65(1.4-53.5)$ & $11.45(0.9-71.0)$ & $21.7(0.7-47.6)$ & $27.45(2.1-70.7)$ & 0.001 \\
\hline
\end{tabular}

Table 3. Comparison of patients remembering or not how long they remain awake at night in terms of obstructive sleep apnea severity and gender

\begin{tabular}{lccc}
\hline & $\begin{array}{c}\text { Remember } \\
(\mathbf{n = 1 0 3})\end{array}$ & $\begin{array}{c}\text { Not Remember } \\
(\mathbf{n = 3 1})\end{array}$ & $\mathbf{p}$ \\
\hline $\begin{array}{l}\text { Gender } \\
\text { Male }\end{array}$ & $69(76.7)$ & $21(23.3)$ & 0.938 \\
Female & $34(77.3)$ & $10(22.7)$ & \\
OSA & & & \\
OSA (+) & $59(68.6)$ & $27(31.4)$ & $\mathbf{0 . 0 0 2}$ \\
OSA (-) & $44(91.7)$ & $4(8.3)$ & \\
OSA & & & \\
None & $44(91.7)$ & $4(8.3)$ & \\
Mild & $27(79.4)$ & $7(20.6)$ & $\mathbf{0 . 0 0 5}$ \\
Moderate & $14(63.6)$ & $8(36.4)$ & \\
Severe & $18(60.0)$ & $12(40.0)$ & \\
\hline $\begin{array}{l}\text { OSA: Obstructive Sleep Apnea, Remember: Patients remember the } \\
\text { awake time they remain during the night, Not Remember: Patients not } \\
\text { remember the awake time they remain during the night }\end{array}$
\end{tabular}

While there was a significant correlation between the sleep time reported by the patients themselves after waking up in the morning and the sleep time measured by the PSG $(\mathrm{p}=0.042, \mathrm{r}=0.301)$ in OSA (-) patients, there was no correlation between the sleep time reported by the patients themselves after waking up in the morning and the sleep time measured by the PSG $(\mathrm{p}=0.269, \mathrm{r}=0.125)$ in OSA $(+)$ patients (Figure 1).

While there was a significant correlation between the sleep latency reported by the patients themselves after waking up in the morning and the sleep latency measured by the PSG ( $p=0.026, r=0.352)$ in OSA (-) patients, there was no correlation between the sleep latency reported by the patients themselves after waking up in the morning and the sleep latency measured by the PSG $(\mathrm{p}=0.060, \mathrm{r}=0.223)$ in OSA (+) patients (Figure 2).

\section{DISCUSSION}

In this study, while there was no significant correlation between PSG measurements and patient's reports regarding to sleep time and latency in patients with OSA, there was a significant correlation in those of patients without OSA. When the rate of remembering the time to stay awake at night was evaluated, we found that the rate of not remembering the awake time was significantly higher in patients with OSA. We found that OSA patients did not correctly perceive the duration of sleep, sleep latency and also did not remember how long they were awake during the night.
Previous studies investigating the effects of OSA on alertness and cognitive functions have demonstrated that apnea recurrence, sleep fragmentation, and nocturnal hypoxemia may affect diurnal behavior, cognitive function, and well-being in these patients. A wide range of cognitive impairment has been identified in OSA patients, from attention and vigilance to memory and executive functions (6).

Castronovo et al. (7) compared 17 OSA patients and 15 healthy controls in terms of functional magnetic resonance imaging (fMRI) scanning and neurocognitive tests in their study. Patients who diagnosed OSA and had no positive airway pressure (PAP) treatment before, treated 3 months with PAP, then compared with the control group. They found that effective PAP treatment is associated with a reduction of activation in prefrontal and hippocampal areas, which parallels an improvement of neuropsychological test performance.

The hippocampus and frontal cortex are closely associated with memory processes and executive functions (8). The intermittent upper airway obstruction during sleep leads to episodic hypoxia, which may be severe with hemoglobin oxygen saturations frequently reaching 50-60\%. In addition, periodic alveolar hypoventilation and repeated arousal either behavioral or electroencephalographic occur leading to sleep fragmentation and deprivation $(9,10)$. Using an experimental model of OSA in rats exposed for 2 weeks to intermittent hypoxia, the authors found a neuronal loss or apoptosis indicating a greater vulnerability of the frontal lobe to hypoxemia (9).

As a result of sleep fragmentation due to respiratory events and respiratory effort, OSA patients are unable to sleep deeply and effectively and their perception of sleep is impaired (11).

A study by Ulukavak Çiftçi et al. (12) evaluated 73 patients divided into two groups according to $\mathrm{AHI}<5$ and $\mathrm{AHI} \geq 5$. In the group with AHI $<5$, sleep history and PSG data were correlated, whereas in the group with AHI $\geq 5$, no correlation was found. As a result of the study, it was found that OSA patients mistakenly perceive their sleep periods. Again, when compared to whether they sleep adequately or not; the group consisting of healthy individuals perceived 2.09 times more accurately.

In our study, patients were similarly divided into two groups as $\mathrm{AHI}<5$ and $\mathrm{AHI} \geq 5$, and when compared in terms of sleep latency and night sleep duration, patient's reports and PSG values were not correlated in the AHI $\geq 5$ group and contrarily, those were correlated in AHI $<5$ group. 

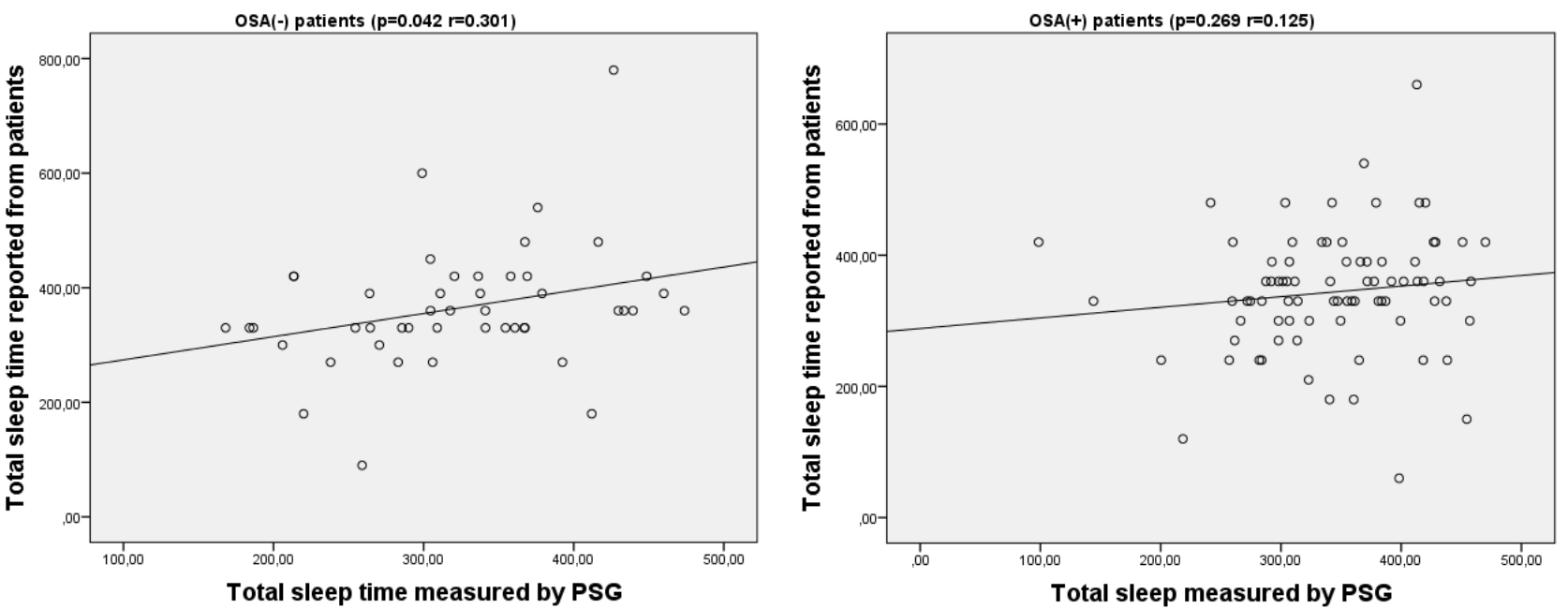

Figure 1. Correlation between sleep duration reported by patients and sleep duration measured by polysomnography
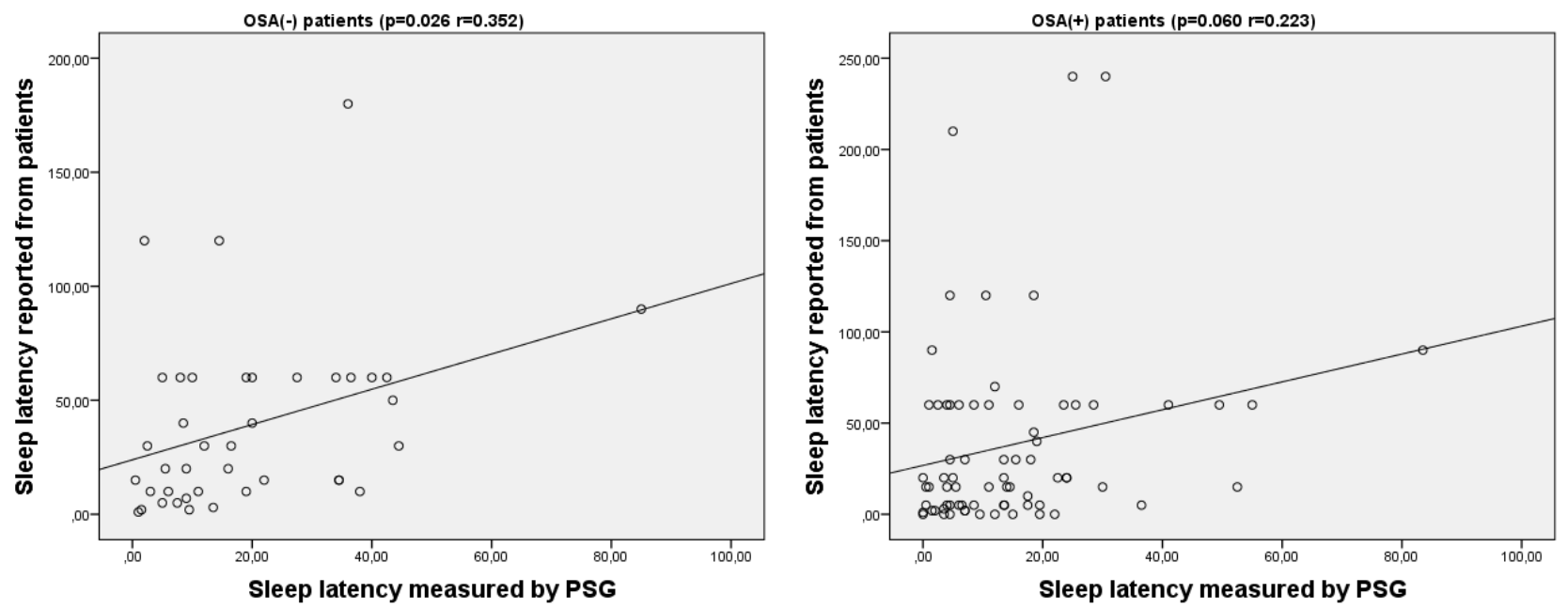

Figure 2. Correlation between sleep latency reported by patients and sleep latency measured by polysomnography

In the study by Savaş Bozbaş et al. (11), although patients stated that they fell asleep after a long time and had difficulty in falling asleep, they found that, the sleep latency evaluated by PSG was shorter than the time declared by the patient. They found that the sleep latency declared by patients and determined by PSG was correlated in the non-OSA group, similar to our study. In our study, we also found that OSA patients did not remember the time to stay awake compared to patients without OSA.

In conclusion, we found that sleep perception of OSA patients was impaired. While evaluating OSA patients and explaining their treatment, it should be kept in mind that they might have impaired perception. We thought that we should spend more time to patients and make our explanations more clearly.

\section{REFERENCES}

1. Yıldız Gülhan P, Güleç Balbay E, Elverişli MF, Erçelik M, Arbak P. Do the levels of particulate matters less than $10 \mu \mathrm{m}$ and seasons affect sleep? Aging Male.
2019;[Epub ahead of print]. doi: 10.1080/13685538.2019.1655637.

2. Knechtle B, Economou NT, Nikolaidis PT, Velentza L, Kallianos A, Steiropoulos P, et al. Clinical characteristics of obstructive sleep apnea in psychiatric disease. J Clin Med. 2019;8(4):E534.

3. Pack AI. Advances in sleep-disordered breathing. Am J Respir Crit Care Med. 2006;173(1):7-15.

4. Bruin PF, Bagnato Mda C. Cognitive impairment in obstructive sleep apnea syndrome. J Bras Pneumol. 2010;36(Suppl 2):32-7.

5. Ağan K, Özmerdivenli R, Değirmenci Y, Çağlar M, Başbuğ A, Guleç Balbay E, et al. Evaluation of sleep in women with menopause: results of the Pittsburg Sleep Quality Index and polysomnography. J Turk Ger Gynecol Assoc. 2015;16(3):149-52.

6. Jackson ML, Howard ME., Barnes M. Cognition and daytime functioning in sleep-related breathing disorders. Prog Brain Res. 2001;190:53-68.

7. Castronovo V, Canessa N, Strambi LF, Aloia MS, Consonni M, Marelli S, et al. Brain activation changes 
before and after PAP treatment in obstructive sleep apnea. Sleep. 2009;32(9):1161-72.

8. Krysta K, Bratek A, Zawada K, Stepańczak R. Cognitive deficits in adults with obstructive sleep apnea compared to children and adolescents. J Neural Transm (Vienna). 2017;124(Suppl 1):187-201.

9. Gozal D, Daniel JM, Dohanich GP. Behavioral and anatomical correlates of chronic episodic hypoxia during sleep in rat. J Neurosci. 2001;21(7):2442-50.
10. Sforza E, Roche F. Sleep apnea syndrome and cognition. Front Neurol. 2012;3:87.

11. Savaş Bozbaş Ş, Arpacı B, Koç P, Öcalan MÇ, Sungur E, Sirin BY. The effect of severity of disease on sleep perception in patients with obstructive sleep apnea. The New Journal of Medicine. 2015;32(1):21-24.

12. Ulukavak Çiftçi T, Köktürk O. Sleep perception and reliability of sleep history in patients admitted to sleep disorders center. Eurasian J Pulmonol. 2005;7(3):103-6. 